\title{
Folic acid binding protein in acute myeloid leukaemia
}

\author{
D. W. GORST, MARY COURTIS, AND I. W. DELAMORE
}

From the Department of Clinical Haematology, University of Manchester and the Royal Infirmary, Manchester

SYNOPSIS Folic acid binding protein was estimated in the serum of 94 control subjects and a normal range was established. Raised levels were found in folate deficiency and chronic myeloid leukaemia. Considerably raised levels were found in untreated acute myeloid leukaemia, most often in cases with a marked monocytic element.

A specific folic acid binding protein (FABP) exists in normal serum (Waxman and Schreiber, 1972), although only a tiny fraction of the serum folate is actually bound. This protein is found mainly in the transferrin peak on column chromatography (Markkanen and Peltola, 1971) and in the transferrin band region in polyacrylamide disc gel electrophoresis (Waxman and Schreiber, 1973); there is a peak at molecular weight 50000 and a further one at 200000 (Waxman and Schreiber, 1973). That it is not transferrin per se was shown by Jacob and Herbert (1974). It is present in increased amounts in folate deficiency (Waxman and Schreiber, 1973) and in both serum and cell lysates from some cases of chronic myeloid leukaemia (CML) (Rothenberg and daCosta, 1971). The physiological role of this protein is unknown.

Although 'serum folate' represents a heterogenous assortment of pteroyl compounds, the folic acid binding protein (FABP) binds pteroylmonoglutamates (PGA) more readily than other components (Waxman, 1975). Using this fact, FABP has been estimated using tritiated PGA to saturate the binders.

\section{Methods}

The method for estimation of FABP was essentially that of Waxman and Schreiber (1973), except that albumin-coated charcoal was used in place of haemologlobin-coated charcoal to avoid the necessity for decolourizing.

\section{PROCEDURE}

Aliquots of $0.4 \mathrm{ml}$ of serum were incubated with $500 \mathrm{pg}$ tritiated PGA ( ${ }^{3} \mathrm{H}$ PGA) in buffer at $37^{\circ} \mathrm{C}$ for Received for publication 15 July 1975.
1 hour. The incubation mixture was added to semi- $\frac{2}{2}$ dried albumin-coated charcoal, incubated for $10<$ minutes at room temperature, and centrifuged and $\vec{\theta}$ the supernatant fluid was removed. This was treated a second time with albumin-coated charcoal to remove as much of the excess ${ }^{3} \mathrm{H}$ PGA as possible. A control for each serum was carried out in an identical manner except that the sample was incubated with $500 \mathrm{ng}$ of cold PGA initially in order to block the binding protein. Any radioactivity $\cong$ remaining after treatment with albumin-coated charcoal is, therefore, not bound to FABP and can be subtracted from the serum result. $0.5 \mathrm{ml}$ of each supernatant fluid was mixed with $4 \mathrm{ml}$ of Instagel and counted on a Phillips liquid scintillation counter together with appropriate standard and blanks. The final results were expressed either as a percentage of 3 . the initial amount of ${ }^{3} \mathrm{H}$ PGA bound by FABP or more conveniently in absolute terms as pg PGA bound per $\mathrm{ml}$ of serum.

The bone marrow aspirates from the patients with acute myeloid leukaemia (AML) were stainedo routinely with May Grünwald Giemsa and examined by several experienced observers: the morphological $O$ diagnoses in each case represent the consensus. In N an attempt to quantify the monocyte component, the aspirates were also stained by the combined $\sigma$ esterase method of Yam et al (1971) and scored for the percentage of reacting cells positive for alpha naphthyl acetate esterase (NAE). Sodium fluoride rendered the score zero in each case. That this stain is highly selective for cells of the monocyte series is shown by the comparative electron microscope $\stackrel{\mathbb{\Phi}}{ }$ studies of Glick and Horn (1974).

Serum lysozyme, unbound $\mathrm{B}_{12}$ binding capacity (UBBC), transcobalamins, serum $B_{12}$, folate, and 


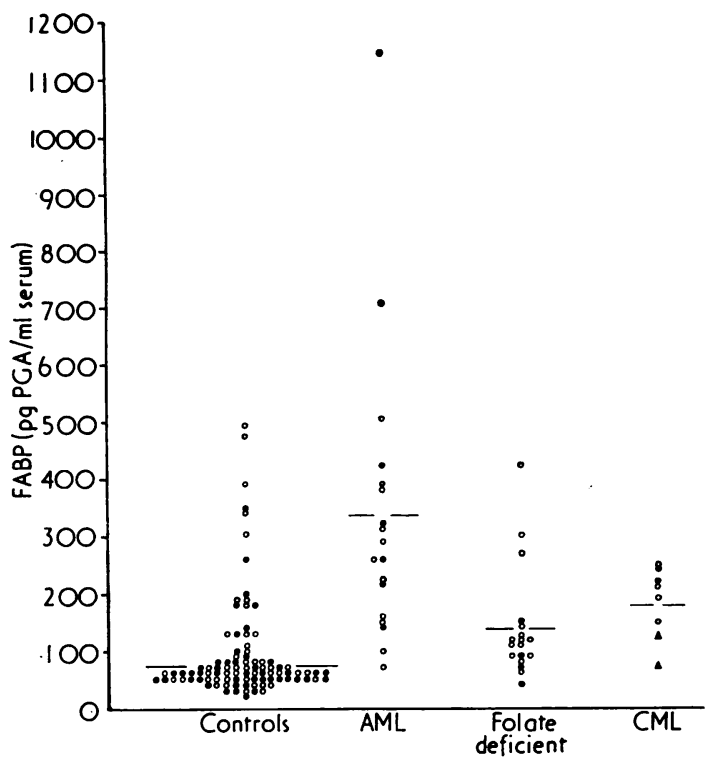

Figure Shows the scatter and the arithmethic means of the levels of FABP (expressed in pg PGA bound per ml of serum) in the four groups, ie, controls, $A M L$, folate deficient, and CML: $\bigcirc$ female, $\bigcirc$ male, $\triangle$ untreated $C M L, \longrightarrow \longrightarrow$ mean level.

ferritin levels were estimated at the same time (see table). Serum (and sometimes RBC) folate was estimated by standard microbiological assay using Lactobacillus casei.

\section{Results}

FABP was estimated in the serum of 94 control subjects. A range of $20-150 \mathrm{pg} / \mathrm{ml}$ was found to encompass $85 \%$ of normal sera, and the mean value was $76 \mathrm{pg} / \mathrm{ml}$. The distribution was skew and was not rendered normal by a logarithmic presentation; for this reason standard deviations are not given. Five apparently normal female subjects had levels in excess of $300 \mathrm{pg} / \mathrm{ml}$. No haematological abnormality could be identified in these people and no ready explanation was advanced: they were not taking oral contraceptive agents.

Eighteen patients found to be folate deficient (mean serum folate $1.2 \mu \mathrm{g} / \mathrm{l}$, mean RBC folate 72 ) were studied and found to have levels of FABP higher than the control subjects. Their mean value was $139 \mathrm{pg} / \mathrm{ml}$.

Eighteen consecutive new cases of AML were studied before treatment and the levels of FABP in the serum were found to be high; the mean value was $338 \mathrm{pg} / \mathrm{ml}$. It was noticeable that some patients with particularly large monocytic components showed exceptionally high levels of FABP.

Eight patients with CML, six of whom were in the terminal blastic phase, were studied. While the mean level of FABP was twice that of the control group (being $179 \mathrm{pg} / \mathrm{ml}$ ), no patient had a level over $260 \mathrm{pg} / \mathrm{ml}$. The two patients with untreated CML and white cell counts of between 6 and $8 \times 10^{11}$ /litre had levels well within the normal range as did a patient with polycythaemia rubra vera and a high white cell count.

Levels of serum ferritin in the AML patients were consistently high, in several cases exceeding 30 times the upper limit of normal (see table).

\section{Discussion}

The finding of high levels of a folate binding protein (normally present in very small amounts) in the serum of patients with untreated AML is unexpected. Folate deficiency may occur in leukaemia (Rose, 1966), but this does not seem to have been the case in most of the patients studied. Not only did the levels of FABP exceed those in severe folate deficiency by a factor of 3 , but the only cases in which slightly low serum folates were found were those in which the folate assay had been performed (of necessity) on serum stored without ascorbic acid. These are marked * in the table and may, of course, be falsely low.

Leukaemic cells are known to produce a variety of substances such as lysozyme (Catovsky et al, 1971), transcobalamins (Catovsky et al, 1972), and ferritin (Parry et al, 1975). In untreated AML specifically, the $\mathrm{B}_{12}$ binding capacity is not consistently raised and in the present study there was no correlation between this and the FABP. The serum lysozyme is thought to be derived in part from the monocyte, and, in general, those of our cases with high lysozyme levels tended to have high NAE scores and high levels of FABP. There was a positive correlation $(r=0.63)$ between FABP and lysozyme levels. The finding of extremely high levels of serum ferritin is in accord with that of other workers (Parry et al, 1975).

Mature granulocytes do not appear to be the major source of this binding protein for even the untreated cases of CML with extremely high white cell counts did not produce levels of FABP as high as in many cases of AML; the levels found were similar to those found in folate deficiency.

The binder in the serum of the AML patients may not be the 'normal' FABP, and no experiments were performed to characterize it. However, it is likely that it will bind folate analogues (such as 


\begin{tabular}{|c|c|c|c|c|c|c|c|c|c|c|c|c|c|c|c|}
\hline Putient & Diagnosis ${ }^{1}$ & $\begin{array}{l}\%+ \\
N A E\end{array}$ & $\begin{array}{c}\text { ve } \begin{array}{l}\text { Serum } \\
\text { folate } \\
(\mu g / l)\end{array}\end{array}$ & $\begin{array}{l}R B C \\
\text { folate } \\
(\mu g / l)\end{array}$ & $\begin{array}{l}F A B P \\
(p g / m l)\end{array}$ & $\begin{array}{l}\text { Ferritin } \\
(n g / m l)\end{array}$ & $\begin{array}{l}U B B C \\
(n g / l)\end{array}$ & $\begin{array}{l}B_{12} \\
(n g / l)\end{array}$ & $\begin{array}{l}\text { TCI! } \\
T C 2\end{array}$ & $\begin{array}{l}\text { Serum } \\
\text { lysozyme } \\
(\mathrm{mg} / \mathrm{l})\end{array}$ & $\begin{array}{l}H b \\
(g / d l)\end{array}$ & $\begin{array}{l}W C C \\
\times 10^{9} / l\end{array}$ & $\begin{array}{l}\text { Platelets } \\
\times 10^{9} / l\end{array}$ & $\begin{array}{l}\% \\
\text { Blasts }\end{array}$ & 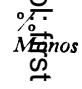 \\
\hline DJ (M) & AMMoL & 70 & $1 \cdot 8^{*}$ & - & 260 & 976 & 516 & 387 & $17 / 83$ & 12 & $8 \cdot 2$ & $2 \cdot 6$ & 187 & - & $1 \overline{5}$ \\
\hline RY (M) & AML & 10 & $1 \cdot 4^{*}$ & - & 218 & 832 & 1015 & 215 & $10 / 90$ & 29 & $7 \cdot 2$ & 1.9 & $<10$ & 10 & $1 \underline{\underline{g}}$ \\
\hline $\mathrm{AC} \quad(\mathrm{M})$ & AMMoL & 22 & $2 \cdot 8$ & 一 & 706 & 2238 & 1372 & 305 & $17 / 83$ & 77 & $7 \cdot 5$ & $10 \cdot 3$ & 53 & 78 & 鸟 \\
\hline $\mathrm{EC} \quad$ (M) & AMMoL & 88 & - & - & 423 & 884 & 1714 & 320 & $19 / 81$ & 225 & $7 \cdot 9$ & $34 \cdot 6$ & 51 & 4 & 88 \\
\hline NW (F) & AMMoL & 71 & $2 \cdot 1$ & 263 & 307 & 1937 & 2178 & 252 & $36 / 44$ & 290 & $8 \cdot 1$ & $25 \cdot 3$ & $<10$ & 2 & 88 \\
\hline WH (M) & $\begin{array}{l}\text { CMMoL/ } \\
\text { AMMoL }\end{array}$ & 73 & $2 \cdot 0^{*}$ & - & 1152 & 3941 & 1026 & 220 & $19 / 18$ & 480 & $8 \cdot 0$ & $85 \cdot 0$ & 74 & 22 & $2 \pi$ \\
\hline KG (F) & AML & 31 & $1 \cdot 8^{*}$ & - & 246 & 2913 & 1475 & 560 & $35 / 65$ & 82 & $5 \cdot 3$ & $143 \cdot 0$ & 30 & 74 & 3 \\
\hline $\mathrm{JC} \quad(\mathrm{M})$ & AML & 13 & $1 \cdot 8^{*}$ & - & 315 & 3376 & 1068 & 695 & $22 / 78$ & 39 & $9 \cdot 5$ & $3 \cdot 4$ & 50 & 26 & \\
\hline BS (F) & AML & 一 & $2 \cdot 0^{*}$ & 一 & 512 & 1181 & 1543 & 192 & $17 / 83$ & 25 & $9 \cdot 9$ & $30 \cdot 0$ & 50 & 3 & 69 \\
\hline BW (F) & AML & 4 & $3 \cdot 9$ & - & 376 & 1745 & 1792 & 675 & $44 / 56$ & 22 & $7 \cdot 7$ & $43 \cdot 2$ & 99 & 12 & $\vec{w}$ \\
\hline MW (F) & AMMoL & 36 & $6 \cdot 4$ & 683 & 151 & 4200 & 3061 & 630 & $16 / 84$ & 77 & $6 \cdot 8$ & $98 \cdot 0$ & 74 & 85 & -8 \\
\hline HE (F) & AMMoL & 45 & 20 & 923 & 163 & 1140 & 903 & 250 & $14 / 86$ & 130 & $7 \cdot 7$ & $24 \cdot 3$ & 257 & 29 & 4क \\
\hline LE (F) & AProMyL & 27 & $>18$ & 1039 & 71 & 2945 & 1171 & 315 & $15 / 85$ & $8 \cdot 5$ & $11 \cdot 8$ & $2 \cdot 4$ & 91 & 5 & \\
\hline $\mathrm{CH}$ (F) & AML & - & $1 \cdot 5$ & 180 & 392 & 1521 & 2313 & 125 & $10 / 90$ & 10 & $7 \cdot 5$ & $2 \cdot 1$ & 38 & - & 3 \\
\hline RG (M) & AML & 26 & 15 & 1260 & 137 & 490 & 522 & 147 & $9 / 91$ & 7 & $8 \cdot 5$ & $9 \cdot 7$ & 55 & 90 & \\
\hline VJ (F) & AMMoL & - & $2 \cdot 5$ & 一 & 99 & 919 & 838 & 157 & $8 / 92$ & 17 & $7 \cdot 5$ & $19 \cdot 9$ & 39 & 78 & -7 \\
\hline MO (F) & AMMoL & 90 & $3 \cdot 1^{*}$ & 一 & 257 & 924 & 2118 & 177 & $12 / 88$ & 218 & $8 \cdot 0$ & $44 \cdot 7$ & 88 & 62 & 18 \\
\hline EB (F) & $\mathbf{A M L} / \mathbf{M F}$ & - & $3 \cdot 2$ & 269 & 289 & 557 & 1264 & 350 & $34 / 66$ & 30 & $10 \cdot 3$ & $24 \cdot 1$ & 82 & 58 & \\
\hline
\end{tabular}

Table Details of results from 18 patients with $A M L$

*see text

${ }^{1} \mathrm{AMMoL}=$ acute myelomonocytic leukaemia; $\mathrm{CMMoL}=$ chronic myelomonocytic leukaemia; $\mathrm{AProMyL}=$ acute promyelocytic leukaemia MF = myelofibrosis

$\mathrm{TC} 1 / \mathrm{TC} 2=$ transcobalamin $1 /$ transcobalamin 2

Methotrexate (MTX)) just as does 'normal' FABP. Although MTX is not used routinely in this country in early AML, this may have implications for the treatment of relapse.

After cytotoxic therapy is begun, levels of FABP fall rapidly. A study is in progress of the levels of FABP throughout treatment, remission, and relapse.

\section{Reagents}

Semidried albumin-coated charcoal is prepared by centrifuging and removing supernatant from $1 \mathrm{ml}$ aliquots of an aqueous solution containing $5 \%$ activated charcoal (BDH lab. reagents) and 1\% bovine albumin (Armour Pharmaceuticals Co Ltd); ${ }^{3} \mathrm{H}$ PGA stock solution containing approximately $20 \mathrm{Ci} / \mathrm{mmol}$ obtained from Radiochemical Centre, Amersham; Stock diluted to $5 \mathrm{ng} / \mathrm{ml}$ in phosphate buffer, $\mathrm{pH} 7 \cdot 4$; Instagel scintillator solution obtained from Packard Instrument Company.

\section{References}

Catovsky, D., Galton, D. A. G., and Griffin, C. (1971). The significance of lysozyme estimations in acute myeloid and chronic monocytic leukaemia. Brit. J. Haemat., 21, 565-580.

Catovsky, D., Ikoku, N. B., Galton, D. A. G., Griffin, C., and Hoff brand, A. V. (1972). Serum lysozyme and vitamin $\mathrm{B}_{12}$ binding capacity in acute myeloid leukaemia. Brit. J. Haemat., 23, (abstract), 263-264.

Glick, A. D. and Horn, R. G. (1974). Identification of promonocytes and monocytoid precursors in acute leukaemia of adults: ultra-structural and cytochemical observations. Brit. J. Haemat., 26, 395-403.

Jacob, E. and Herbert, V. (1974). Evidence against transferrin as a binder of either vitamin $B_{12}$ or folic acid. Blood, 43, 767-768.

Markkanen, T. and Peltola, O. (1971). Carrier proteins of folic acid activity in human serum. Acta haemat., 45 , 106-111.

Parry, D. H., Worwood, M., and Jacobs, A. (1975). Serum ferritin in acute leukaemia at presentation and during remission. Brit. med. J., 1, 245-247.

Rose, D. P. (1966). Folic acid deficiency in leukaemia and lymphomas. J. clin. Path., 19, 29-32.

Rothenberg, S. P. and daCosta, M. (1971). Further observations on the folate-binding factor in some leukemic cells. J. clin. Invest., 50, 719-726.

Waxman, S. (1975). Folate binding proteins. Brit.J. Haemat., 옥 29, 23-29.

Waxman, S. and Schreiber, C. (1972). Measurements of serum folate and folic acid binding proteins by ${ }^{3} \mathrm{HPGA}$ radioassay. Clin. Res., $20,572$.

Waxman, S. and Schreiber, C. (1973). Characteristics of $N$ folic acid-binding protein in folate-deficient serum. Blood, 42, 291-301.

Yam, L. T., Li, C. Y., and Crosby, W. H. (1971). Cytochemical identification of monocytes and granulocytes. Amer. J. clin. Path., 55, 283-290. 